\title{
Value At Risk pada Portofolio Saham dengan Copula Ali-Mikhail-Haq
}

\author{
Delsy Nurutsaniyah ${ }^{1}$, Tatik Widiharih' ${ }^{2}$, Di Asih I Maruddani ${ }^{3}$ \\ 1,2,3 Departemen Statistika, Fakultas Sains dan Matematika, Universitas Diponegoro \\ delsysaniyah@gmail.com
}

\begin{abstract}
Investment is one alternative to increase assets in the future. Investors can invest in a portfolio to reduce the level of risk. Value at Risk (VaR) is a measuring tool that can calculate the worst loss over a given time period at a given confidence level. GARCH (Generalized Autoregressive Conditional Heteroskedasticity) is used to model data with high volatility. The teory of copula is a powerful tool for modeling joint distribution for any marginal distributions. Ali-Mikhail-Haq copula from Archimedean copula family can be applied to data with dependencies $\tau$ between -0.1817 to 0.3333 . This research uses AliMikhail-Haq copula with a Monte Carlo simulation to calculate a bivariate portfolio VaR from a combination stocks of PT Pembangunan Perumahan Tbk. (PTPP), PT Bank Tabungan Negara Tbk. (BBTN), and PT Jasa Marga Tbk. (JSMR) in the period of March 3, 2014 - March 1, 2019. The results of VaR calculation on bivariate portfolio for next 1 day period obtained the lowest VaR is owned by bivariate portfolio between PTPP and JSMR with a weight of $30 \%$ and $70 \%$ at confidence level of $99 \%, 95 \%$, and $90 \%$ respectively are $4.014 \%, 2.545 \%$, and $1.876 \%$.
\end{abstract}

Keywords: Value at Risk, GARCH, Ali-Mikhail-Haq Copula, Monte Carlo

\section{PENDAHULUAN}

Investasi merupakan komitmen atas sejumlah dana atau sumber daya lainnya yang dilakukan pada saat ini, dengan tujuan memperoleh sejumlah keuntungan di masa datang (Tandelilin, 2010). Saham merupakan tanda penyertaan atau pemilikan individu maupun kelompok dalam suatu perusahaan atau perseroan terbatas (Darmadji dan Fakhruddin, 2012). Investor dapat melakukan portofolio saham yaitu dengan melakukan investasi pada dua saham atau lebih secara bersamaan. Seorang investor dalam mengendalikan risiko perlu suatu alat, salah satunya yaitu Value at Risk (VaR). VaR merupakan alat ukur untuk menghitung kerugian terburuk yang akan diderita selama periode waktu tertentu dalam kondisi pasar normal pada tingkat kepercayaan tertentu (Jorion, 2006). Ada beberapa pendekatan untuk menghitung VaR yaitu metode varian-kovarian, simulasi historis, dan simulasi Monte Carlo. Menurut Jorion (2006), simulasi Monte Carlo sejauh ini merupakan metode yang paling kuat untuk mengukur VaR karena dapat menjelaskan berbagai eksposur dan risiko termasuk risiko harga non-linier, risiko volatilitas dan bahkan risiko model. Penelitian ini akan menggunakan metode simulasi Monte Carlo dengan pendekatan copula.

Copula adalah alat yang sangat ampuh untuk memodelkan distribusi bersama karena tidak memerlukan asumsi normalitas sehingga cukup fleksibel untuk berbagai data terutama data keuangan (Palaro dan Hotta, 2006). Salah satu metode copula yang sering digunakan adalah metode copula-GARCH (Generalized Autoregressive Conditional Heteroscedasticity). GARCH biasanya digunakan untuk memodelkan data yang memiliki volatilitas tinggi seperti data saham. Pada penelitian ini akan menggunakan copula AliMikhail-Haq. Menurut Kumar (2010), copula Ali-Mikhail-Haq merupakan copula dari keluarga copula Archimedean yang parameternya berada pada interval [-1,1] dan dapat 
menyatakan dependensi baik negatif maupun positif. Copula Ali-Mikhail-Haq dapat diaplikasikan pada data yang memiliki dependensi $\tau$ antara $-0,1817$ sampai dengan 0,3333.

Pada penelitian ini akan dilakukan perhitungan VaR portofolio bivariat dari kombinasi saham PT Pembangunan Perumahan Tbk. (PTPP), PT Bank Tabungan Negara Tbk. (BBTN), dan PT Jasa Marga Tbk. (JSMR) periode 3 Maret 2014 sampai 1 Maret 2019 menggunakan metode copula-GARCH dengan simulasi Monte Carlo dan copula yang digunakan adalah copula Ali-Mikhail-Haq.

\section{TINJAUAN PUSTAKA}

\subsection{Return Saham}

Return saham yang disebut juga sebagai pendapatan saham merupakan perubahan nilai harga saham periode $t$ dengan $t-1$ (Hanafi dan Halim, 1996). Tsay (2002) menyatakan nilai return dapat dihitung dengan rumus:

$$
r_{t}=\ln \frac{P_{t}}{P_{t-1}}
$$

dimana $P_{t}$ adalah harga saham periode sekarang dan $P_{t-1}$ adalah harga saham periode sebelumnya. Rumus return portofolio dari $n$ aset pada waktu ke- $t$ dapat ditulis sebagai berikut (Jorion, 2006):

$$
r_{p t}=\sum_{i=1}^{n} w_{i} r_{i t}
$$

dimana $r_{i t}$ adalah return aset ke- $i$ pada waktu ke- $t$ dan $w_{i}$ adalah bobot setiap alokasi dana untuk aset tunggal ke- $i$.

\subsection{Analisis Runtun Waktu}

Dasar pemikiran runtun waktu adalah pengamatan sekarang $\left(Z_{t}\right)$ tergantung pada satu atau beberapa pengamatan sebelumnya $\left(Z_{t-k}\right), k=1,2, \ldots, q$. Dengan kata lain, model runtun waktu dibuat karena secara statistik ada korelasi (dependen) antar deret pengamatan (Makridakis et al., 1999).

\subsection{Model Box-Jenkins}

Model Box-Jenkins merupakan pemodelan runtun waktu yang diperkenalkan oleh Box dan Jenkins pada tahun 1970. Model runtun waktu stasioner adalah model AR, MA, dan ARMA sedangkan model runtun waktu tidak stasioner adalah model ARIMA, dengan model sebagai berikut:

a. Model Autoregressive (AR)

$$
Z_{t}=\phi_{1} Z_{t-1}+\phi_{2} Z_{t-2}+\cdots+\phi_{p} Z_{t-p}+a_{t}
$$

b. Model Moving Average (MA)

$$
Z_{t}=a_{t}-\theta_{1} a_{t-1}-\theta_{2} a_{t-2}-\cdots-\theta_{q} a_{t-q}
$$

c. Model Autoregressive Moving Average (ARMA)

$$
Z_{t}=\phi_{1} Z_{t-1}+\cdots+\phi_{p} Z_{t-p}+a_{t}-\theta_{1} a_{t-1}-\cdots-\theta_{q} a_{t-q}
$$

d. Model Autoregressive Integrated Moving Average (ARIMA)

$$
\phi_{p}(B)(1-B)^{d} Z_{t}=\theta_{q}(B) a_{t}
$$

\subsection{Tahapan Pemodelan Runtun Waktu}

\subsubsection{Identifikasi Model}


Identifikasi model dapat dilakukan melalui pemeriksaan plot ACF (Autocorrelation Function) dan PACF (Partial Autocorrelation Function). ACF berfungsi untuk menentukan orde $q$ dalam model MA. ACF didefinisikan sebagai berikut:

$$
\rho_{k}=\frac{\operatorname{Cov}\left(Z_{t}, Z_{t+k}\right)}{\sqrt{\operatorname{Var}\left(Z_{t}\right)} \sqrt{\operatorname{Var}\left(Z_{t+k}\right)}}=\frac{\gamma_{k}}{\gamma_{0}}
$$

Sedangkan PACF berfungsi untuk menentukan orde $p$ dalam model AR. PACF didefinisikan sebagai berikut:

$$
\emptyset_{k k}=\frac{\left|\begin{array}{cccccc}
1 & \rho_{1} & \rho_{2} & \ldots & \rho_{k-2} & \rho_{1} \\
\rho_{1} & 1 & \rho_{1} & \ldots & \rho_{k-3} & \rho_{2} \\
\vdots & \vdots & \vdots & & \vdots & \vdots \\
\rho_{k-1} & \rho_{k-2} & \rho_{k-3} & \ldots & \rho_{1} & \rho_{k}
\end{array}\right|}{\left|\begin{array}{cccccc}
1 & \rho_{1} & \rho_{2} & \ldots & \rho_{k-2} & \rho_{k-1} \\
\rho_{1} & 1 & \rho_{1} & \ldots & \rho_{k-3} & \rho_{k-2} \\
\vdots & \vdots & \vdots & & \vdots & \vdots \\
\rho_{k-1} & \rho_{k-2} & \rho_{k-3} & \ldots & \rho_{1} & 1
\end{array}\right|}
$$

\subsubsection{Estimasi dan Uji Signifikansi Parameter Model}

Menurut Wei (2006), estimasi parameter dapat dilakukan dengan metode momen, Maximum Likelihood, dan Least Squares. Uji signifikansi parameter dilakukan dengan prosedur sebagai berikut:

Hipotesis:

$\mathrm{H}_{0}: \psi_{i}=0$ (parameter tidak signifikan terhadap model)

$\mathrm{H}_{1}: \psi_{i} \neq 0$ (parameter signifikan terhadap model)

dimana $\psi$ merupakan parameter dalam model

Taraf signifikansi: $\alpha$

Statistik uji:

$$
t_{\text {hitung }}=\frac{\hat{\psi}_{i}}{S E\left(\hat{\psi}_{i}\right)}
$$

Kriteria uji:

$\mathrm{H}_{0}$ ditolak jika $\left|t_{\text {hitung }}\right|>t_{(\alpha / 2, n-p)}$ atau $p$-value $<\alpha$, dimana $p$ adalah banyaknya parameter.

\subsubsection{Verifikasi Model}

\subsubsection{Uji Independensi Residual}

Uji independensi residual digunakan untuk mengetahui ada tidaknya korelasi residual antar lag. Uji yang digunakan adalah uji Ljung-Box.

Hipotesis:

$\mathrm{H}_{0}: \rho_{1}=\rho_{2}=\cdots=\rho_{K}=0$ (tidak ada korelasi residual antar lag)

$\mathrm{H}_{1}$ : paling sedikit ada satu $\rho_{k} \neq 0$ dengan $k=1,2, \ldots, K$ (ada korelasi residual antar lag) Taraf signifikansi: $\alpha$

Statistik uji:

$$
Q=n(n+2) \sum_{k=1}^{K}(n-k)^{-1} \hat{\rho}_{k}^{2}
$$

dimana $n=$ banyaknya data, $K=$ banyaknya lag yang diuji, dan $\hat{\rho}_{k}=$ autokorelasi residual pada lag ke- $k$. $Q$ berdistribusi chi-kuadrat dengan derajat bebas $m$.

Kriteria uji:

$\mathrm{H}_{0}$ ditolak jika $Q_{(m)}>\chi_{(K-m)}^{2}$ atau $p$-value $<\alpha$. 


\subsubsection{Uji Normalitas Residual}

Uji normalitas digunakan untuk mengetahui apakah residual dari model mengikuti distribusi normal. Uji yang digunakan adalah uji Jarque Bera.

Hipotesis:

$\mathrm{H}_{0}$ : Residual berdistribusi normal

$\mathrm{H}_{1}$ : Residual tidak berdistribusi normal

Taraf signifikansi: $\alpha$

Statistik uji:

$$
J B=\frac{n}{6}\left(S^{2}+\frac{(K-3)^{2}}{4}\right)
$$

dimana $n$ adalah banyaknya data, $S$ adalah skewness, dan $K$ adalah kurtosis.

Kriteria uji:

$\mathrm{H}_{0}$ ditolak jika $J B>\chi_{(2)}^{2}$ atau $p$-value $<\alpha$.

\subsubsection{Uji Lagrange Multiplier}

Uji Lagrange Multiplier dapat digunakan untuk mendeteksi adanya efek ARCH/GARCH.

Hipotesis:

$\mathrm{H}_{0}: \alpha_{1}=\alpha_{2}=\cdots=\alpha_{k}=0$ (tidak ada efek ARCH/GARCH dalam residual sampai lag ke-k)

$\mathrm{H}_{1}$ : paling sedikit ada satu nilai $\alpha_{i} \neq 0, i=1,2, \ldots, k$ (ada efek ARCH/GARCH dalam residual sampai lag ke-k)

Taraf signifikansi: $\alpha$

Statistik uji:

$$
L M=n R^{2}
$$

dimana $n$ adalah banyaknya data dan $R^{2}$ adalah nilai koefisien determinasi

Kriteria uji:

$\mathrm{H}_{0}$ ditolak jika nilai $L M>\chi_{(k)}^{2}$ atau $p$-value $<\alpha$.

\subsection{Model Autoregressive Conditional Heterokedasticity (ARCH) dan Generalized Autoregressive Conditional Heterokedasticity (GARCH)}

Model ARCH diperkenalkan oleh Engle pada tahun 1982 untuk mengatasi masalah heteroskedastisitas. Bentuk umum model $\operatorname{ARCH}(m)$ yaitu (Tsay, 2002):

$$
\begin{gathered}
a_{t}=\sigma_{t} \epsilon_{t} \\
\sigma_{t}^{2}=\alpha_{0}+\alpha_{1} a_{t-1}^{2}+\cdots+\alpha_{m} a_{t-m}^{2}
\end{gathered}
$$

dengan $\alpha_{0}>0$, dan $\alpha_{i} \geq 0$ untuk $i=1,2, \ldots, m$. Pada tahun 1986, Bollerslev mengembangkan model ARCH yang dikenal sebagai model GARCH. Bentuk umum model $\operatorname{GARCH}(m, s)$ yaitu (Tsay, 2002):

$$
\sigma_{t}^{2}=\alpha_{0}+\sum_{i=1}^{a_{t}=\sigma_{t} \epsilon_{t}} \alpha_{i} a_{t-i}^{2}+\sum_{j=1}^{s} \beta_{j} \sigma_{t-j}^{2}
$$

dengan $\alpha_{0}>0, \alpha_{i} \geq 0$, dan $\beta_{j} \geq 0$, dan $\sum_{i, j=1}^{\max (m, s)}\left(\alpha_{i}+\beta_{j}\right)<1$ untuk $i=1,2, \ldots, m$ dan $j=$ $1,2, \ldots, s$.

\subsection{Pemilihan Model Terbaik}

Pemilihan model terbaik dapat dilakukan dengan menggunakan metode AIC (Akaike's Information Criterion). Nilai AIC dapat diperoleh dengan rumus (Wei, 2006):

$$
A I C=n L n \hat{\sigma}_{a}^{2}+2 M
$$


dimana $n=$ banyaknya data, $M=$ banyaknya parameter yang diduga dalam model, dan $\hat{\sigma}_{a}^{2}=$ estimator maksimum likelihood dari $\sigma_{a}^{2}$.

\subsection{Uji Mutual Dependensi}

Uji mutual dependensi dilakukan untuk mengetahui ada tidaknya dependensi antara variabel dalam pemodelan distribusi bersama. Joe (1997) memperkenalkan pengukuran dependensi yang digunakan dalam copula yaitu tail dependence, Tau Kendall $(\tau)$, dan Rho Spearman $(\rho)$. Dalam penelitian ini, digunakan korelasi Tau Kendall yang didefinisikan sebagai berikut (Nelsen, 2006):

$$
\tau=\frac{P-Q}{P+Q}=\frac{P-Q}{\left(\begin{array}{c}
n \\
2
\end{array}\right)}
$$

dimana $P=$ jumlah pasangan konkordan dan $Q=$ jumlah pasangan diskordan.

Hipotesis:

$\mathrm{H}_{0}: \tau=0$ (tidak ada korelasi antar variabel)

$\mathrm{H}_{1}: \tau \neq 0$ (ada korelasi antar variabel)

Taraf signifikansi: $\alpha$

Statistik uji:

$$
Z_{\text {hitung }}=\frac{|\tau| \sqrt{9 n(n-1)}}{\sqrt{2(2 n+5)}}
$$

Kriteria uji:

$\mathrm{H}_{0}$ ditolak jika $Z_{\text {hitung }}>Z_{\alpha / 2}$ atau $p$-value $<\alpha$.

\subsection{Copula}

Kata copula berasal dari bahasa latin yang berarti mengikat. Menurut Nelsen (2006), copula merupakan suatu fungsi distribusi bersama hasil dari penggabungan marginalmarginalnya yang berdistribusi uniform $[0,1]$. Copula dibagi menjadi beberapa keluarga, keluarga copula yang paling populer digunakan adalah copula Ellips yang terdiri dari copula Gaussian dan copula Student-t, serta copula Archimedean yang terdiri dari copula Gumbel, copula Frank, copula Clayton, copula Ali-Mikhail-Haq, dan copula Joe.

\subsubsection{Copula Ali-Mikhail-Haq}

Copula Ali-Mikhail-Haq merupakan salah satu anggota dari keluarga copula Archimedean. Fungsi distribusi bivariat copula Ali-Mikhail-Haq didefinisikan (Nelsen, 2006):

$$
C\left(u_{1}, u_{2}\right)=\frac{u_{1} u_{2}}{1-\theta\left(1-u_{1}\right)\left(1-u_{2}\right)}
$$

dimana $u_{i}=F_{i}\left(x_{i}\right) \in[0,1]$ dan parameter copula $\theta \in[-1,1]$.

\subsubsection{Estimasi Parameter Copula Ali-Mikhail-Haq}

Estimasi parameter copula dengan pendekatan Tau Kendall dapat dihitung dengan rumus (Nelsen, 2006):

$$
\hat{\tau}=1+4 \int_{0}^{1} \frac{\phi(u)}{\phi^{\prime}(u)} d u
$$

dimana $\hat{\tau}$ adalah nilai korelasi Tau Kendall dan $\phi(u)$ adalah fungsi pembangkit copula AliMikhail-Haq yaitu $\phi(u)=\ln [1-\theta(1-u)] / u$. Diperoleh estimasi parameter $\theta$ copula Ali-Mikhail-Haq dengan pendekatan Tau Kendall sebagai berikut:

$$
\hat{\tau}=\frac{3 \theta-2}{3 \theta}-\frac{2(1-\theta)^{2} \ln (1-\theta)}{3 \theta^{2}}
$$


Persamaan tersebut bersifat nonlinier sehingga untuk mencari nilai estimasi parameter $\theta$ digunakan metode numerik, salah satunya dapat menggunakan metode NewtonRaphson.

\subsection{Value at Risk}

Value at Risk (VaR) merupakan alat ukur untuk menghitung kerugian terburuk yang akan didapat selama periode waktu tertentu dalam kondisi pasar normal pada tingkat kepercayaan tertentu (Jorion, 2006). Nilai VaR pada tingkat kepercayaan (1- $\alpha$ ) dalam periode waktu $t$ hari pada return tunggal maupun portofolio dapat dihitung dengan rumus:

$$
\operatorname{VaR}_{(1-\alpha)}(t)=W_{0} R^{*} \sqrt{t}
$$

dimana $W_{0}=$ dana investasi awal, $R^{*}=$ nilai kuantil ke- $\alpha$ dari distribusi return.

Dalam mengestimasi nilai VaR dengan simulasi Monte Carlo mempunyai beberapa jenis algoritma. Namun pada intinya adalah melakukan simulasi dengan membangkitkan bilangan acak berdasarkan karakteristik dari data yang akan dibangkitkan, kemudian digunakan untuk mengestimasi nilai VaR.

\section{METODOLOGI PENELITIAN}

Data yang digunakan adalah data harga penutupan saham harian pada tiga perusahaan di Indonesia yaitu PT Pembangunan Perumahan Tbk. (PTPP), PT Bank Tabungan Negara Tbk. (BBTN), dan PT Jasa Marga Tbk. (JSMR) periode 3 Maret 2014 - 1 Maret 2019. Data saham tersebut dapat diakses pada www.finance.yahoo.com.

Langkah-langkah yang dilakukan dalam melakukan perhitungan VaR portofolio bivariat dari kombinasi tiga saham menggunakan metode copula-GARCH dengan simulasi Monte Carlo dan copula yang digunakan adalah copula Ali-Mikhail-Haq adalah:

a. Menghitung nilai return saham dari masing-masing saham.

b. Menganalisis secara deskriptif masing-masing return saham.

c. Melakukan uji stasioneritas masing-masing return saham. Jika return saham tidak stasioner dalam varian maka dilakukan transformasi Box-Cox. Jika return saham tidak stasioner dalam mean maka dilakukan diferensi.

d. Membentuk plot ACF dan plot PACF dari masing-masing return saham yang telah stasioner dalam mean dan varian.

e. Melakukan identifikasi model ARIMA masing-masing return saham.

f. Melakukan estimasi dan uji signifikansi parameter model masing-masing return saham.

g. Melakukan verifikasi model ARIMA yang meliputi uji independensi residual, uji normalitas residual, dan uji Lagrange Multiplier.

h. Memilih model ARIMA terbaik berdasarkan nilai AIC terkecil.

i. Melakukan identifikasi model ARIMA-GARCH.

j. Melakukan estimasi dan uji signifikansi parameter model ARIMA-GARCH.

k. Melakukan uji normalitas residual model ARIMA-GARCH.

1. Menghitung korelasi Tau Kendall antar masing-masing residual return saham dan melakukan uji mutual dependensi.

m. Mengestimasi parameter copula Ali-Mikhail-Haq dan membentuk copula Ali-MikhailHaq.

n. Menghitung VaR dengan menggunakan pembangkitan data dari copula Ali-MikhailHaq dengan simulasi Monte Carlo.

\section{HASIL DAN PEMBAHASAN}

\subsection{Karakteristik Return Saham}




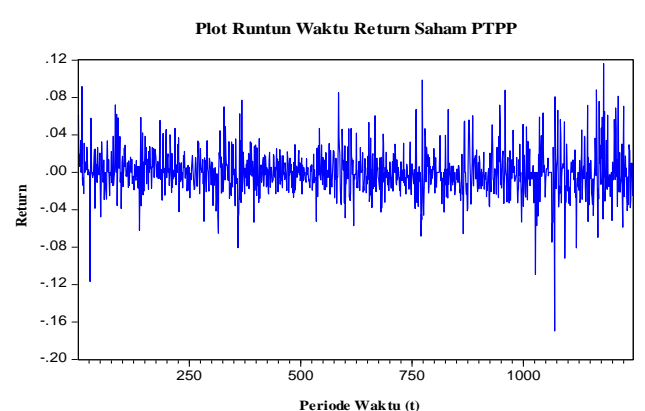

(a)

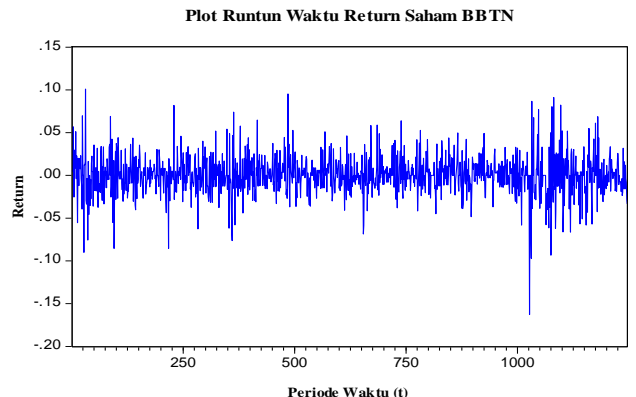

(b)

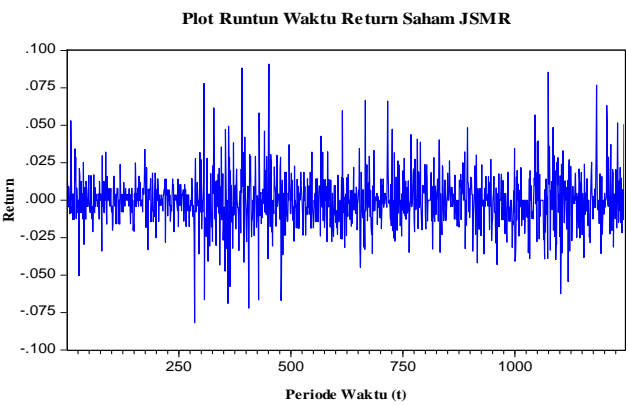

(c)

\section{Gambar 1. Plot Runtun Waktu Return Saham (a) PTPP (b) BBTN (c) JSMR}

Gambar 1 menunjukkan bahwa terdapat volatility clustering yaitu adanya pengelompokan volatilitas pada periode waktu berdekatan. Selain itu, pada Gambar 1 juga menunjukkan return pada ketiga saham telah stasioner dalam mean secara visual.

\subsection{Pemodelan Runtun Waktu}

Dalam pemodelan runtun waktu, langkah awal adalah memeriksa kestasioneran data. Uji stasioneritas dalam varian digunakan Transformasi Box-Cox dan diperoleh nilai rounded value sebesar 1, artinya semua return saham telah stasioner dalam varian. Uji stasioneritas dalam mean secara formal dilakukan dengan menggunakan uji Augmented Dickey Fuller dan didapatkan kesimpulan bahwa semua return saham telah stasioner dalam mean.

Tabel 1 menunjukkan model dugaan ARIMA beserta estimasi dan uji signifikansi parameter model ARIMA dari masing-masing saham. 
Tabel 1. Estimasi dan Uji Signifikansi Parameter Model ARIMA

\begin{tabular}{|c|c|c|c|c|c|}
\hline Saham & Model & Parameter & Estimasi & p-value & Kesimpulan \\
\hline \multirow{8}{*}{ PTPP } & \multirow{2}{*}{ ARIMA $([1,3], 0,0)$} & $\phi_{1}$ & 0,072525 & 0,0103 & Signifikan \\
\hline & & $\phi_{3}$ & $-0,074848$ & 0,0080 & Signifikan \\
\hline & \multirow{2}{*}{$\operatorname{ARIMA~}(0,0,[1,3])$} & $\theta_{1}$ & 0,078511 & 0,0055 & Signifikan \\
\hline & & $\theta_{3}$ & $-0,070695$ & 0,0123 & Signifikan \\
\hline & \multirow{2}{*}{ ARIMA $([1], 0,[3])$} & $\phi_{1}$ & 0,074427 & 0,0085 & Signifikan \\
\hline & & $\theta_{3}$ & $-0,072676$ & 0,0104 & Signifikan \\
\hline & \multirow{2}{*}{ ARIMA ([3],0,[1]) } & $\phi_{3}$ & $-0,074729$ & 0,0083 & Signifikan \\
\hline & & $\theta_{1}$ & 0,077805 & 0,0061 & Signifikan \\
\hline \multirow{5}{*}{ BBTN } & ARIMA $([28], 0,0)$ & $\phi_{28}$ & $-0,081948$ & 0,0036 & Signifikan \\
\hline & \multirow{2}{*}{ ARIMA $(0,0,[12,28])$} & $\theta_{12}$ & $-0,064992$ & 0,0215 & Signifikan \\
\hline & & $\theta_{28}$ & $-0,091895$ & 0,0012 & Signifikan \\
\hline & \multirow{2}{*}{ ARIMA ([28],0,[12]) } & $\phi_{28}$ & $-0,081124$ & 0,0040 & Signifikan \\
\hline & & $\theta_{12}$ & $-0,061618$ & 0,0322 & Signifikan \\
\hline \multirow{2}{*}{ JSMR } & $\operatorname{ARIMA~}([2], 0,0)$ & $\phi_{2}$ & $-0,085041$ & 0,0027 & Signifikan \\
\hline & ARIMA $(0,0,[2])$ & $\theta_{2}$ & $-0,088366$ & 0,0018 & Signifikan \\
\hline
\end{tabular}

Uji independensi residual dengan uji Ljung-Box menunjukkan bahwa p-value dari masing-masing model ARIMA saham PTPP dan JSMR > 0,05 sehingga $\mathrm{H}_{0}$ diterima, maka disimpulkan bahwa tidak ada korelasi residual antar lag. Sedangkan pada saham BBTN hanya model ARIMA $(0,0,[12,28])$ yang tidak ada korelasi residual antar lag.

Uji normalitas residual model ARIMA dengan uji Jarque Bera diperoleh hasil seperti pada Tabel 2.

Tabel 2. Uji Jarque Bera Residual Model ARIMA

\begin{tabular}{cccc}
\hline Saham & Model & $\boldsymbol{p}$-value & Kesimpulan \\
\hline \multirow{5}{*}{ PTPP } & ARIMA $([1,3], 0,0)$ & 0,0000 & Tidak berdistribusi normal \\
& ARIMA $(0,0,[1,3])$ & 0,0000 & Tidak berdistribusi normal \\
& ARIMA $([1], 0,[3])$ & 0,0000 & Tidak berdistribusi normal \\
& ARIMA $([3], 0,[1])$ & 0,0000 & Tidak berdistribusi normal \\
\hline \multirow{3}{*}{ BBTN } & ARIMA $([28], 0,0)$ & 0,0000 & Tidak berdistribusi normal \\
& ARIMA $(0,0,[12,28])$ & 0,0000 & Tidak berdistribusi normal \\
& ARIMA $([28], 0,[12])$ & 0,0000 & Tidak berdistribusi normal \\
\hline \multirow{2}{*}{ JSMR } & ARIMA $([2], 0,0)$ & 0,0000 & Tidak berdistribusi normal \\
& ARIMA $(0,0,[2])$ & 0,0000 & Tidak berdistribusi normal \\
\hline
\end{tabular}

Pemilihan model ARIMA terbaik masing-masing saham berdasarkan nilai AIC terkecil diperoleh hasil seperti pada Tabel 3.

Tabel 3. Pemilihan Model ARIMA Terbaik

\begin{tabular}{ccl}
\hline Saham & \multicolumn{1}{c}{ Model } & Nilai AIC \\
\hline \multirow{3}{*}{ PTPP } & ARIMA $([1,3], 0,0)$ & $-4,623351$ \\
\cline { 2 - 3 } & ARIMA $(0,0,[1,3])$ & $-4,619922$ \\
\cline { 2 - 3 } & ARIMA $([1], 0,[3])$ & $\left.-4,624177^{*}\right)$ \\
\cline { 2 - 3 } & ARIMA $([3], 0,[1])$ & $-4,623713$ \\
\hline \multirow{2}{*}{ BBTN } & ARIMA $(0,0,[12,28])$ & $-4,705584^{(*)}$ \\
\hline \multirow{2}{*}{ JSMR } & ARIMA $([2], 0,0)$ & $-5,184137$ \\
\cline { 2 - 3 } & ARIMA $(0,0,[2])$ & $\left.-5,185352^{*}\right)$ \\
\hline
\end{tabular}


Model ARIMA terbaik untuk saham PTPP adalah ARIMA ([1],0,[3]), saham BBTN adalah ARIMA $(0,0,[12,28])$, dan saham JSMR adalah ARIMA $(0,0,[2])$.

\subsection{Uji Lagrange Multiplier}

Uji Lagrange Multiplier digunakan untuk mendeteksi ada tidaknya efek ARCH/GARCH pada residual model. Hasil uji Lagrange Multiplier diberikan pada Tabel 4.

Tabel 4. Uji Lagrange Multiplier Model ARIMA

\begin{tabular}{cccc}
\hline Saham & Model & p-value & Kesimpulan \\
\hline PTPP & ARIMA $([1], 0,[3])$ & 0,0000 & Ada efek ARCH/GARCH \\
\hline BBTN & ARIMA $(0,0,[12,28])$ & 0,0081 & Ada efek ARCH/GARCH \\
\hline JSMR & ARIMA $(0,0,[2])$ & 0,0000 & Ada efek ARCH/GARCH \\
\hline
\end{tabular}

\subsection{Pemodelan ARIMA-GARCH}

Identifikasi model ARIMA-GARCH awal yang terbentuk untuk saham PTPP adalah ARIMA ([1],0,[3]) GARCH (1,1), ARIMA ([1],0,[3]) GARCH (2,1), dan ARIMA ([1],0,[3]) GARCH $(1,2)$, untuk saham BBTN adalah ARIMA $(0,0,[12,28])$ GARCH $(1,1)$, serta untuk saham JSMR adalah ARIMA $(0,0,[2])$ GARCH $(1,1)$. Tabel 5 menunjukkan model dugaan ARIMA beserta estimasi dan uji signifikansi parameter model ARIMAGARCH dari masing-masing saham.

Tabel 5. Estimasi dan Uji Signifikansi Parameter Model ARIMA-GARCH

\begin{tabular}{|c|c|c|c|c|c|}
\hline Saham & Model & Parameter & Estimasi & p-value & Kesimpulan \\
\hline \multirow{17}{*}{ PTPP } & \multirow{5}{*}{$\begin{array}{l}\text { ARIMA }([1], 0,[3]) \\
\operatorname{GARCH}(1,1)\end{array}$} & $\phi_{1}$ & 0,069500 & 0,0148 & Signifikan \\
\hline & & $\theta_{3}$ & $-0,095650$ & 0,0004 & Signifikan \\
\hline & & $\alpha_{0}$ & 0,0000159 & 0,0000 & Signifikan \\
\hline & & $\alpha_{1}$ & 0,058541 & 0,0000 & Signifikan \\
\hline & & $\beta_{1}$ & 0,914175 & 0,0000 & Signifikan \\
\hline & \multirow{6}{*}{$\begin{array}{l}\text { ARIMA }([1], 0,[3]) \\
\quad \operatorname{GARCH}(2,1)\end{array}$} & $\phi_{1}$ & 0,069026 & 0,0278 & Signifikan \\
\hline & & $\theta_{3}$ & $-0,095464$ & 0,0002 & Signifikan \\
\hline & & $\alpha_{0}$ & 0,00000997 & 0,0000 & Signifikan \\
\hline & & $\alpha_{1}$ & 0,120810 & 0,0001 & Signifikan \\
\hline & & $\alpha_{2}$ & $-0,077148$ & 0,0145 & Signifikan \\
\hline & & $\beta_{1}$ & 0,939182 & 0,0000 & Signifikan \\
\hline & \multirow{6}{*}{$\begin{array}{l}\text { ARIMA }([1], 0,[3]) \\
\quad \operatorname{GARCH}(1,2)\end{array}$} & $\phi_{1}$ & 0,068524 & 0,0238 & Signifikan \\
\hline & & $\theta_{3}$ & $-0,098680$ & 0,0005 & Signifikan \\
\hline & & $\alpha_{0}$ & 0,0000242 & 0,0000 & Signifikan \\
\hline & & $\alpha_{1}$ & 0,091457 & 0,0000 & Signifikan \\
\hline & & $\beta_{1}$ & 0,243684 & 0,0252 & Signifikan \\
\hline & & $\beta_{2}$ & 0,622886 & 0,0000 & Signifikan \\
\hline \multirow{5}{*}{ BBTN } & \multirow{5}{*}{$\begin{array}{c}\text { ARIMA }(0,0,[12,28]) \\
\operatorname{GARCH}(1,1)\end{array}$} & $\theta_{12}$ & $-0,054304$ & 0,0677 & Tidak signifikan \\
\hline & & $\theta_{28}$ & $-0,072565$ & 0,0051 & Signifikan \\
\hline & & $\alpha_{0}$ & 0,0000305 & 0,0002 & Signifikan \\
\hline & & $\alpha_{1}$ & 0,061374 & 0,0000 & Signifikan \\
\hline & & $\beta_{1}$ & 0,879524 & 0,0000 & Signifikan \\
\hline \multirow{3}{*}{ JSMR } & \multirow{3}{*}{$\begin{array}{l}\text { ARIMA }(0,0,[2]) \\
\text { GARCH }(1,1)\end{array}$} & $\theta_{2}$ & $-0,089174$ & 0,0032 & Signifikan \\
\hline & & $\alpha_{0}$ & 0,000169 & 0,0000 & Signifikan \\
\hline & & $\alpha_{1}$ & 0,245236 & 0,0000 & Signifikan \\
\hline
\end{tabular}


Model ARIMA-GARCH saham BBTN terdapat parameter yang tidak signifikan, maka parameter yang tidak signifikan dihapus dari model sehingga model baru yang terbentuk adalah ARIMA $(0,0,[28])$ GARCH $(1,1)$. Tabel 6 menunjukkan estimasi beserta uji signifikansi parameter model ARIMA $(0,0,[28])$ GARCH $(1,1)$ saham BBTN.

Tabel 6. Estimasi dan Uji Signifikansi Parameter Model ARIMA-GARCH Lanjutan

\begin{tabular}{lccccc}
\hline Saham & Model & Parameter & Estimasi & $\boldsymbol{p}$-value & Kesimpulan \\
\hline \multirow{3}{*}{ BBTN } & & $\theta_{28}$ & $-0,072578$ & 0,0054 & Signifikan \\
& ARIMA $(0,0,[28])$ & $\alpha_{0}$ & 0,0000289 & 0,0001 & Signifikan \\
& GARCH $(1,1)$ & $\alpha_{1}$ & 0,059719 & 0,0000 & Signifikan \\
& & $\beta_{1}$ & 0,884620 & 0,0000 & Signifikan \\
\hline
\end{tabular}

Pemilihan model ARIMA-GARCH terbaik masing-masing saham berdasarkan nilai AIC terkecil diperoleh hasil seperti pada Tabel 7.

Tabel 7. Pemilihan Model ARIMA-GARCH Terbaik

\begin{tabular}{ccc}
\hline Saham & Model & Nilai AIC \\
\hline & $\begin{array}{c}\text { ARIMA ([1],0,[3]) } \\
\text { GARCH }(1,1)\end{array}$ & $-4,698402$ \\
\cline { 2 - 3 } PTPP & $\begin{array}{c}\text { ARIMA ([1],0,[3]) } \\
\text { GARCH }(2,1)\end{array}$ & $-4,700441$ \\
\cline { 2 - 3 } & $\begin{array}{c}\text { ARIMA ([1],0,[3]) } \\
\text { GARCH }(1,2)\end{array}$ & $-4,701582^{(*)}$ \\
\hline \multirow{2}{*}{ BBTN } & $\begin{array}{c}\text { ARIMA }(0,0,[12,28]) \\
\text { GARCH }(1,1)\end{array}$ & $-4,775530^{(*)}$ \\
\hline \multirow{2}{*}{ JSMR } & $\begin{array}{c}\text { ARIMA }(0,0,[2]) \\
\text { GARCH }(1,1)\end{array}$ & $-5,242604^{(*)}$ \\
\hline
\end{tabular}

Persamaan mean dan varian pada model ARIMA-GARCH terbaik yang dihasilkan pada masing-masing saham adalah:

a. PTPP

$$
\begin{aligned}
& Z_{t}=0,068524 Z_{t-1}+a_{t}-0,09868 a_{t-3} \\
& \sigma_{t}^{2}=0,0000242+0,091457 a_{t-1}^{2}+0,243684 \sigma_{t-1}^{2}+0,622886 \sigma_{t-2}^{2}
\end{aligned}
$$

b. BBTN

$$
\begin{array}{ll} 
& Z_{t}=a_{t}-0,072578 a_{t-28} \\
& \sigma_{t}^{2}=0,0000289+0,059719 a_{t-1}^{2}+0,884620 \sigma_{t-1}^{2} \\
\text { c. } & \text { JSMR } \\
& Z_{t}=a_{t}-0,089174 a_{t-2} \\
& \sigma_{t}^{2}=0,000169+0,245236 a_{t-1}^{2}+0,255412 \sigma_{t-1}^{2}
\end{array}
$$

Uji normalitas residual model ARIMA-GARCH dengan uji Jarque Bera diperoleh hasil seperti pada Tabel 8.

Tabel 8. Uji Jarque Bera Residual Model ARIMA-GARCH

\begin{tabular}{cccc}
\hline Saham & Model & p-value & Kesimpulan \\
\hline PTPP & $\begin{array}{c}\text { ARIMA ([1],0,[3]) } \\
\text { GARCH }(1,2)\end{array}$ & 0,0000 & Tidak berdistribusi normal \\
\hline \multirow{2}{*}{ BBTN } & $\begin{array}{c}\text { ARIMA }(0,0,[28]) \\
\text { GARCH }(1,1)\end{array}$ & 0,0000 & Tidak berdistribusi normal \\
\hline
\end{tabular}




\begin{tabular}{cccc} 
JSMR & $\begin{array}{c}\text { ARIMA }(0,0,[2]) \\
\text { GARCH }(1,1)\end{array}$ & 0,0000 & Tidak berdistribusi normal \\
\hline
\end{tabular}

\subsection{Copula}

Residual model ARIMA-GARCH yang tidak berdistribusi normal selanjutnya dilakukan uji mutual dependensi untuk mengetahui apakah ada dependensi antara masingmasing residual. Uji mutual dependensi antar residual diperoleh hasil seperti pada Tabel 9.

Tabel 9. Uji Mutual Dependensi dengan Korelasi Tau Kendall

\begin{tabular}{ccccc}
\hline Saham & $\boldsymbol{\tau}$ & $\boldsymbol{Z}_{\text {hitung }}$ & p-value & Kesimpulan \\
\hline PTPP-BBTN & 0,2144312 & 11,338 & $<2,2 \mathrm{e}-16$ & Ada korelasi \\
PTPP-JSMR & 0,1945541 & 10,287 & $<2,2 \mathrm{e}-16$ & Ada korelasi \\
BBTN-JSMR & 0,1988774 & 10,515 & $<2,2 \mathrm{e}-16$ & Ada korelasi \\
\hline
\end{tabular}

Nilai korelasi Tau Kendall berada di interval -0,1817 sampai dengan 0,3333 sehingga dalam melakukan distribusi gabungan dapat dilanjutkan dengan copula Ali-Mikhail-Haq.

Hasil estimasi parameter copula Ali-Mikhail-Haq dengan pendekatan Tau Kendall diberikan pada Tabel 10.

Tabel 10. Estimasi Parameter Copula Ali-Mikhail-Haq

\begin{tabular}{cc}
\hline Saham & Parameter $(\boldsymbol{\theta})$ \\
\hline PTPP-BBTN & 0,7516 \\
PTPP-JSMR & 0,6987 \\
BBTN-JSMR & 0,7105 \\
\hline
\end{tabular}

Persamaan model copula Ali-Mikhail-Haq untuk residual ARIMA-GARCH antar masing-masing saham adalah:

a. PTPP dengan BBTN

b. PTPP dengan JSMR

$$
C_{0,7516}^{A M H}\left(u_{1}, u_{2}\right)=\frac{u_{1} u_{2}}{1-0,7516\left(1-u_{1}\right)\left(1-u_{2}\right)}
$$

$$
C_{0,6987}^{A M H}\left(u_{1}, u_{2}\right)=\frac{u_{1} u_{2}}{1-0,6987\left(1-u_{1}\right)\left(1-u_{2}\right)}
$$

c. BBTN dengan JSMR

$$
C_{0,7105}^{A M H}\left(u_{1}, u_{2}\right)=\frac{u_{1} u_{2}}{1-0,7105\left(1-u_{1}\right)\left(1-u_{2}\right)}
$$

\subsection{Perhitungan Value at Risk}

Perhitungan VaR pada portofolio bivariat dari kombinasi saham PTPP, BBTN, dan JSMR akan dilakukan untuk jangka waktu satu hari ke depan pada tingkat kepercayaan 99\%, 95\%, dan 90\% menggunakan simulasi Monte Carlo dengan membangkitkan sebanyak 1246 data dan pengulangan sebanyak 3000 kali. Hasil perhitungan VaR pada portofolio bivariat saham PTPP dan BBTN diberikan pada Tabel 11.

Tabel 11. Perhitungan VaR Portofolio Saham PTPP dan BBTN dengan Beberapa Bobot

\begin{tabular}{ccccc}
\hline \multicolumn{2}{c}{ Bobot Portofolio } & \multicolumn{3}{c}{ Value at Risk } \\
\hline PTPP & BBTN & $\mathbf{9 9 \%}$ & $\mathbf{9 5 \%}$ & $\mathbf{9 0 \%}$ \\
\hline 0,1 & 0,9 & $-0,05788266$ & $-0,03237160$ & $-0,02325519$ \\
0,2 & 0,8 & $-0,05389178$ & $-0,03087689$ & $-0,02234231$ \\
0,3 & 0,7 & $-0,05091215$ & $-0,03005227$ & $-0,02183597$ \\
0,4 & 0,6 & $-0,04880393$ & $-0,02951918$ & $-0,02152057$
\end{tabular}




\begin{tabular}{lllll}
0,5 & 0,5 & $-0,04737677$ & $-0,02943334$ & $-0,02151768^{(*)}$ \\
0,6 & 0,4 & $-0,04751025$ & $-0,02956204$ & $-0,02176854$ \\
0,7 & 0,3 & $-0,04855793$ & $-0,03010067$ & $-0,02226842$ \\
0,8 & 0,2 & $-0,05090665$ & $-0,03106744$ & $-0,02301714$ \\
0,9 & 0,1 & $-0,05414691$ & $-0,03246746$ & $-0,02391373$ \\
\hline
\end{tabular}

Berdasarkan Tabel 11, diperoleh bobot terbaik untuk investasi pada saham PTPP dan BBTN masing-masing sebesar 50\%. Apabila diilustrasikan, seorang investor menanamkan investasi sebesar Rp 100 juta maka kerugian maksimal yang akan diderita pada tingkat kepercayaan 99\%, 95\%, dan 90\% secara berurutan mencapai Rp 4.737.677,00; Rp 2.943.334,00; dan Rp 2.151.768,00 dalam jangka waktu satu hari.

Hasil perhitungan VaR pada portofolio bivariat saham PTPP dan JSMR diberikan pada Tabel 12 .

Tabel 12. Perhitungan VaR Portofolio Saham PTPP dan JSMR dengan Beberapa Bobot

\begin{tabular}{ccccc}
\hline \multicolumn{2}{c}{ Bobot Portofolio } & \multicolumn{3}{c}{ Value at Risk } \\
\hline PTPP & JSMR & $\mathbf{9 9 \%}$ & $\mathbf{9 5 \%}$ & $\mathbf{9 0 \%}$ \\
\hline 0,1 & 0,9 & $-0,04185638$ & $-0,02685304$ & $-0,01941579$ \\
0,2 & 0,8 & $-0,04051153$ & $-0,02589522$ & $-0,01897534$ \\
0,3 & 0,7 & $-0,04013966$ & $-0,02544737$ & $-0,01875996^{(*)}$ \\
0,4 & 0,6 & $-0,04027625$ & $-0,02547015$ & $-0,01903727$ \\
0,5 & 0,5 & $-0,04085995$ & $-0,02596576$ & $-0,01938822$ \\
0,6 & 0,4 & $-0,04269075$ & $-0,02696337$ & $-0,02011804$ \\
0,7 & 0,3 & $-0,04564297$ & $-0,02828485$ & $-0,02108478$ \\
0,8 & 0,2 & $-0,04932624$ & $-0,02992329$ & $-0,02221973$ \\
0,9 & 0,1 & $-0,05369317$ & $-0,03204774$ & $-0,02358142$ \\
\hline
\end{tabular}

Berdasarkan Tabel 12, diperoleh bobot terbaik untuk investasi pada saham PTPP sebesar 30\% dan JSMR sebesar 70\%. Apabila diilustrasikan, seorang investor menanamkan investasi sebesar Rp 100 juta maka kerugian maksimal yang akan diderita pada tingkat kepercayaan 99\%, 95\%, dan 90\% secara berurutan mencapai Rp 4.013.966,00; Rp 2.544.737,00; dan Rp 1.875.996,00 dalam jangka waktu satu hari.

Hasil perhitungan VaR pada portofolio bivariat saham PTPP dan JSMR diberikan pada Tabel 13.

Tabel 13. Perhitungan VaR Portofolio Saham BBTN dan JSMR dengan Beberapa Bobot

\begin{tabular}{ccccc}
\hline \multicolumn{2}{c}{ Bobot Portofolio } & \multicolumn{3}{c}{ Value at Risk } \\
\hline BBTN & JSMR & $\mathbf{9 9 \%}$ & $\mathbf{9 5 \%}$ & $\mathbf{9 0 \%}$ \\
\hline 0,1 & 0,9 & $-0,04183370$ & $-0,02683034$ & $-0,01937719$ \\
0,2 & 0,8 & $-0,04065680$ & $-0,02585013$ & $-0,01888409$ \\
0,3 & 0,7 & $-0,04023787$ & $-0,02550880$ & $-0,01877402^{(*)}$ \\
0,4 & 0,6 & $-0,04062261$ & $-0,02563509$ & $-0,01888059$ \\
0,5 & 0,5 & $-0,04187364$ & $-0,02612543$ & $-0,01912612$ \\
0,6 & 0,4 & $-0,04448918$ & $-0,02696450$ & $-0,01967809$ \\
0,7 & 0,3 & $-0,04818866$ & $-0,02817551$ & $-0,02049152$ \\
0,8 & 0,2 & $-0,05261493$ & $-0,02977038$ & $-0,02157329$ \\
0,9 & 0,1 & $-0,05732815$ & $-0,03191872$ & $-0,02287592$ \\
\hline
\end{tabular}

Berdasarkan Tabel 13, diperoleh bobot terbaik untuk investasi pada saham BBTN sebesar 30\% dan JSMR sebesar 70\%. Apabila diilustrasikan, seorang investor menanamkan investasi sebesar Rp 100 juta maka kerugian maksimal yang akan diderita pada tingkat 
kepercayaan 99\%, 95\%, dan 90\% secara berurutan mencapai Rp 4.023.787,00; Rp 2.550.880,00; dan Rp 1.877.402,00 dalam jangka waktu satu hari.

Dari hasil perhitungan VaR portofolio bivariat pada kombinasi saham PTPP, BBTN, dan JSMR, diperoleh VaR portofolio terendah yaitu VaR portofolio pada saham PTPP dengan bobot 30\% dan JSMR dengan bobot $70 \%$.

\section{KESIMPULAN}

Berdasarkan hasil dan pembahasan, diperoleh kesimpulan sebagai berikut:

1. Pemodelan ARIMA-GARCH pada data return saham PTPP, BBTN, dan JSMR adalah:

a. PTPP

$$
\begin{aligned}
& Z_{t}=0,068524 Z_{t-1}+a_{t}-0,09868 a_{t-3} \\
& \sigma_{t}^{2}=0,0000242+0,091457 a_{t-1}^{2}+0,243684 \sigma_{t-1}^{2}+0,622886 \sigma_{t-2}^{2}
\end{aligned}
$$

b. BBTN

$$
\begin{array}{ll} 
& Z_{t}=a_{t}-0,072578 a_{t-28} \\
& \sigma_{t}^{2}=0,0000289+0,059719 a_{t-1}^{2}+0,884620 \sigma_{t-1}^{2} \\
\text { c. } & \text { JSMR } \\
& Z_{t}=a_{t}-0,089174 a_{t-2} \\
& \sigma_{t}^{2}=0,000169+0,245236 a_{t-1}^{2}+0,255412 \sigma_{t-1}^{2}
\end{array}
$$

2. Hasil estimasi parameter copula Ali-Mikhail-Haq menggunakan pendekatan Tau Kendall antara residual ARIMA-GARCH saham PTPP dengan BBTN yaitu $\theta=0,7516$; PTPP dengan JSMR yaitu $\theta=0,6987$; dan BBTN dengan JSMR yaitu $\theta=0,7105$. Sehingga model copula Ali-Mikhail-Haq yang terbentuk adalah:

a. PTPP dengan BBTN

$$
C_{0,7516}^{A M H}\left(u_{1}, u_{2}\right)=\frac{u_{1} u_{2}}{1-0,7516\left(1-u_{1}\right)\left(1-u_{2}\right)}
$$

b. PTPP dengan JSMR

$$
C_{0,6987}^{A M H}\left(u_{1}, u_{2}\right)=\frac{u_{1} u_{2}}{1-0,6987\left(1-u_{1}\right)\left(1-u_{2}\right)}
$$

c. BBTN dengan JSMR

$$
C_{0,7105}^{A M H}\left(u_{1}, u_{2}\right)=\frac{u_{1} u_{2}}{1-0,7105\left(1-u_{1}\right)\left(1-u_{2}\right)}
$$

3. Hasil perhitungan VaR pada portofolio bivariat untuk jangka waktu satu hari ke depan dengan simulasi Monte Carlo dengan membangkitkan 1246 data dari parameter copula Ali-Mikhail-Haq sebanyak 3000 kali pengulangan yaitu untuk portofolio bivariat saham PTPP dan BBTN dengan bobot masing-masing 50\% serta tingkat kepercayaan 99\%, 95\%, dan 90\% secara berurutan adalah sebesar -0,04737677; -0,02943334; dan -0,02151768. Pada portofolio bivariat saham PTPP dengan bobot 30\% dan JSMR dengan bobot $70 \%$ serta tingkat kepercayaan 99\%, 95\%, dan 90\% secara berurutan adalah sebesar 0,04013966; -0,02544737; dan -0,01875996. Pada portofolio bivariat saham BBTN dengan bobot 30\% dan JSMR dengan bobot 70\% serta tingkat kepercayaan 99\%, 95\%, dan $90 \%$ secara berurutan adalah sebesar -0,04023787; -0,0255088; dan -0,01877402.

\section{DAFTAR PUSTAKA}

Darmadji dan Fakhruddin. 2012. Pasar Modal di Indonesia. Jakarta: Salemba Empat.

Hanafi, H. dan Halim, A. 1996. Analisa Laporan Keuangan. Yogyakarta: UPP STIM YKPN.

Joe, H. 1997. Multivariate Models and Dependence Concepts. New York: Chapman \& Hall. 
Jorion, P. 2006. Value at Risk: The New Benchmark for Managing Financial Risk Third Edition. New York: McGraw Hill.

Kumar, P. 2010. Probability Distributions and Estimation of Ali-Mikhail-Haq Copula. Applied Mathematical Sciences Vol. 4, No. 14: Hal. 657 - 666.

Makridakis, S., Wheelwright, S. C., dan McGee, V. E. 1999. Metode dan Aplikasi Peralaman. Edisi Kedua. Diterjemahkan oleh: Andriyanto dan Basith. Jakarta: Erlangga. Terjemahan dari: Forecasting Methods and Applications Second Edition.

Nelsen, R. B. 2006. An Introduction to Copulas Second Edition. New York: Springer Science+Business Media.

Palaro, H. P. dan Hotta, L. K. 2006. Using Conditional Copula to Estimate Value at Risk. Journal of Data Science, No. 4: Hal. 93-115.

Tandelilin, E. 2010. Portofolio dan Investasi Teori dan Aplikasi. Yogyakarta: Kanisius.

Tsay, R. S. 2002. Analysis of Financial Time Series. Canada: John Willey \& Sons.

Wei, W.W.S. 2006. Time Series Analysis: Univariate and Multivariate Methods Second Edition. US: Pearson Addison Wesley. 